\title{
INTERCROPPING POTENTIAL OF OIL PALM (E. GUINEENSIS JACQ.) AND LIBERICA COFFEE (C. LIBERICA L.): A CASE STUDY IN SMALLHOLDER PLANTATION
}

\author{
Erick Firmansyah*, Arif Umami \\ Faculty of Agriculture, Stiper Institute of Agriculture, Yogyakarta, Indonesia \\ *Corresponding author \\ Email: erick@instiperjogja.ac.id*, umamiarif@instiperjogja.ac.id
}

\begin{abstract}
Oil palm (Elaeis guineensis Jacq.) has become the main plantation commodity in Indonesia. Climate change phenomena and competitiveness fluctuation of palm oil commodities have led to increased need for optimized land productivity while maintaining sustainability. This research aimed to study the potential of oil palm intercropping with liberica coffee (Coffea liberica L.) in several smallholder oil palm plantations in Riau Province, Sumatera Island, Indonesia. Measurements in the middle of the non-harvesting path of oil palm showed the age of oil palm is directly proportional to the difference between air and soil temperature and relative humidity under canopy. Oil palm roots were dominantly distributed vertically in solum $0-30 \mathrm{~cm}$ and always dominant compared to coffee at all horizontal distances observed. While the dominant root coffee distribution was in solum $31-60 \mathrm{~cm}$. Analysis results show the tap roots extend no further than 30-45 cm below the soil surface. It was known that oil palm roots are dominantly distributed at a distance of 2-3 $m$ from the trunk while the coffee roots are dominantly distributed at a distance of 1-2 $\mathrm{m}$ from the trunk. Analysis of oil palm yields in the intercropping system showed no significant decrease compared to monocropping systems with relatively the same age and production input. Coffee production per tree has decreased by 25-30\% compared to the average production in monocropping systems.
\end{abstract}

Keywords: intercropping; oil palm; liberica; coffee

\section{Introduction}

Oil palm (Elaeis guineensis Jacq.) has become the most rapidly expanding equatorial crops in the world during the past few decades. In 2007, oil palm is cultivated in one-tenth of the world's permanent cropland (Koh \& Wilcove, 2008). Since 2006, Indonesia has become the country with the most extensive oil palm plantation and the highest production of palm oil in the world. Oil palm is the most recently introduced plant to Indonesia compared to other commodities such as coffee (1696), sugar cane (1595), tea (1684), and cocoa (1560). Palm oil was introduced to Indonesia by the Dutch East Indies government in 1848. However, today oil palm is becoming the main plantation commodity in Indonesia.

Based on the status and size of the concession, $41 \%$ of the total area of Indonesian oil palm plantation is smallholder plantation, while private and estate owned plantation respectively $54 \%$ and $5 \%$. In 2018, the area cultivated by smallholders was estimated to reach 5.8 million hectare of the total oil palm plantation in Indonesia (Anonim, 2019).

Smallholder plantations have the lowest productivity compared to estate and private plantation. In 2015, their productivity reached 18.94 and 20.15 ton $^{-1}$ year $^{-1}$ respectively, while smallholder 
plantation only reached 16.44 ton $\mathrm{ha}^{-1}$ year $^{-1}$. Crude palm oil (CPO) productivity from smallholder plantations had only 2.5 ton $\mathrm{ha}^{-1}$ year ${ }^{-1}$, far from the average productivity of private and state plantation which reached 4-6 ton $\mathrm{ha}^{-1}$ year $^{-1}$. The data showed that the average production yield of public and private large estates was 25\% greater than smallholders yield (Anonim, 2019).

Increased competitiveness of other vegetable oil-producing crops against palm oil due to falling CPO prices, encourages the need for efforts to diversify sources of income for farmers (Goh, 2000). So far, palm oil is almost always cultivated in monocropping system. The high level of business profits and the pattern of developing oil palm plantations are the main factors causing farmers to use a monocropping system in oil palm cultivation.

Plantation managers (farmers) are currently faced with challenges to optimize the potential of existing land in order to obtain land productivity as high as possible while maintaining environmental sustainability. In addition, CPO commodity price fluctuations are a threat to the sustainability of smallholders' oil palm business.

In West Africa (the origin of oil palm) is a part of agroforestry which is cultivated in a polyculture or intercropping manner both with food crops and other permanent tree crops (Khasanah et al., 2016). Climate change phenomena and competitiveness fluctuation of palm oil commodities have led to increase an interest of intercropping cultivation system. The purposes of intercropping are to diversify income and to optimize the use of available resources from the same land area.

At present, the practices of intercropping in oil palm plantation are commonly with annual crops and carried out when oil palm has not produced yet ( 0 - 3 years after planting/YAP). Their canopy had not yet met, so that sunlight penetration could reach the surface of the frond of annual crops (Harun et al., 2018; Trisna et al., 2018). Meanwhile, intercropping practice in produced plants ( $>4$ YAP) is very rare, even it is almost never done by estate, private and smallholder plantation. The intercropping system with annual crops has several deficiencies that is not massively adopted. Intensive management is needed in terms of inputs (fertilizers, pesticides, and herbicides) and labor to ensure its success.

Efforts are needed to explore intercropping possibilities between oil palm and other plants, especially annual crops. This research aimed to study the potential of oil palm intercropping with liberica coffee (Coffea liberica L.) in several smallholder oil palm plantations. The benefit of this research is considered important in order to improve the sustainability of the oil palm cultivation system in terms of economy and environment. 


\section{Methods}

\subsection{General information of Research Location}

This research was carried out in smallholder oil palm plantation in Kepenuhan Raya Village, Rokan Hulu Regency, Riau Province in the island of Sumatera. It was conducted in July 2018 September 2019. The research location has a flat topographic area of 0 - 50 meter above sea level and shallow peat soil type. The climatic characteristics are very suitable for oil palm growth. Overall based on topography, physical, and chemical properties of the soil, as well as climatic conditions, the category of research's site is a highly suitable for oil palm growth (class S1).

Three (3) conditions of oil palm block were used in this research, namely oil palm 5 YAP (PP 2), 8 YAP (PP 5), and 12 YAP (PP 9), in which PP (production phase) term means plant commence to produce commercial fresh fruit bunch. Oil palm plants were planted with a uniform spacing, which is a triangle form, $9 \times 9 \times 9 \mathrm{~m}$ (142 Stands Per Hectare).

In other hand, Liberica coffee plants are ranged between 4-5 YAP. They were planted in nonharvesting path with spacing in $4 \mathrm{~m}$ rows and spacing between $7.8 \mathrm{~m}$ rows (320 plants per hectare). Oil palm and coffee plants maintenance consist of fertilizing, pruning, managing pests and desease, and without irrigation system.

\subsection{Research Methods}

A case study method with a quantitative descriptive approach was used in this research. Descriptive quantitative research methods are research methods which are used to examine natural conditions of objects. Data was obtained by interview of smallholders and direct observation.

\subsection{Data analysis}

Primary data observed were (1) microclimate (consisting of sunlight intensity, air temperature under the canopy, soil temperature, radiation energy, and relative humidity. Measurements are taken 3 times a day, from 08.00 - $09.00 \mathrm{am}, 12.00$ - $13.00 \mathrm{pm}$, and 16.00 - $17.00 \mathrm{pm}$; (2) distribution of oil palm and coffee roots. Measurements of the vertical distribution were carried out on 3 different solums (0 - $30 \mathrm{~cm}, 31-60 \mathrm{~cm}$, and $61-90 \mathrm{~cm})$, while measurement of the horizontal distribution was carried out at 4 different distances from stems (100, 200, 300, and $400 \mathrm{~cm})$; (3) oil palm and coffee production.

Root dry mass analysis for oil palm and coffee were conducted according to the method develop by Vicente et al. (2017). After removal from each solum, soil and root samples were placed on a $2 \mathrm{~mm}$ mesh sieve. With the aid of water jets, roots were separated from the soil. Subsequently, roots were dried in an oven at $80{ }^{\circ} \mathrm{C}$ for 24 hours to achieve constant mass. Dry mass was determined in an analytical scale. The distribution of oil palm and coffee roots in several solum were shown in Figure 1.

Based on preliminary identification, it was known that there were 60 farmers who practice oil 
palm-coffee intercropping, consisting of 15 farmers in 5 YAP, 25 farmers in 8 YAP, and 20 farmers in 12 YAP. Data obtained were processed into a database for later analysis with descriptive analysis methods using IBM SPSS Statistics 24.

\section{Results and Discussion}

\subsection{Microclimate under oil palm stands}

Climatic conditions on a narrow land area, a few meters from the ground surface, or under the plant canopy is called microclimate. Often the conditions of the microclimate are very different from the general climatic conditions around it. According to Kingra and Kaur (2017) this allows several plants to grow side by side and interact positively as long as their growing environment is in appropriate microclimate.

Based on observation, it is known that there were differences in the amount of oil palm fronds that were left at different plant ages. At 5 YAP, there were an average of 56 fronds, while at ages 8 and 12 YAP the number of fronds were 52 and 40 fronds respectively. This number of fronds are optimum according to Perez et al. (2017) and Luskin and Potts (2011). Their difference was influenced and adjusted by harvesting technique and tool.

At the age of 5 YAP, the oil palm height was still quite short. Therefore, Fresh Fruit Bunch (FFB) harvesting could be done using chisel (dodos). It allows harvester cut the FFB without cutting the supporting fronds. Increased plant height at 8 and 12 YAP caused chisel could be unsuitable so harvester switched to using sickle (egrek). The harvester who used sickle then needed to cut off the supporting fronds first to cut FFB. Number of fronds maintained by smallholder farmers was in accordance with Turner and Gillbanks (1974) and Perez et al. (2017) which stated that to optimize the photosynthesis process and productivity, preferably for young plants ( $\leq 8$ years) the number of fronds is maintained in the range of 48-56 fronds, while in mature plants ( $>8$ years) maintained in the range of 40-48 fronds.

Measurements of plant height (from stem base to the lowest frond) showed that 5 YAP plants had an average height of $1.75 \mathrm{~m}$, while plants aged 8 and 12 YAP had 3 and $4.5 \mathrm{~m}$ height, respectively. The difference in the number of fronds and plant height affected the intensity of light under the stand of oil palms. Frond length was measured from the base of the petiole to the tip of the rachis (Perez et al., 2017). Frond length in 8 YAP oil palm or more is relatively stable, ranging from $4-4.2 \mathrm{~m}$.

Measurements in the middle of the dead row of oil palm plants (non-harvesting path) showed there are significant variability in light radiation intensity under the canopy. Average light radiation intensity under the canopy of 5 YAP plants reached $44.3 \%$, while those in plants aged 8 and 12 YAP experienced $64.6 \%$ and $83.3 \%$ compared above the plant canopy. The increased 
intensity of irradiation under the canopy of older plant was not only due to the reduced number of fronds but also the presence of saturated light.

Although there is a decrease, the intensity of light observed under the stand in the entire age range of the oil palm is still in the range suitable for coffee growth. According to Ceulemans and Saugier (1993) compared to other annual crops, coffee has a low rate of net $\mathrm{CO}_{2}$ assimilation, typically in the range of $4-11 \mathrm{mmol} \mathrm{m}^{-2} \mathrm{~s}^{-1}$ so that it can take place at saturating light.

Coffee evolved in the forest as an understorey tree, and thus it was considered to be shadeobligatory (Damatta et al., 2007). The protective effects of shading have been associated with the lower radiation input at the level of the coffee canopy, which may reduce the extent of photooxidative damages, a phenomenon frequently observed in coffee grown at full exposure in marginal zones, and ultimately increases crop life expectance (da Matta, 2004). Shade may positively affect bean size and composition as well as beverage quality (lesser bitterness and astringency) by delaying and synchronizing berry ripening (Vaast et al., 2006).

Increased plant height will decrease horizontal barriers from oil palm fronds. Its allowed not only light to reach into soil surface, but also the air movement (wind) that decrease relative air humidity. Air humidity has a significant impact on the vegetative growth and fertilization of the coffee tree. Relative humidity in 8 YAP and 12 YAP compare to 5 YAP decreased 7.8 and 8.4\%, respectively. It had a significant effect on the microclimate under oil palm stands (Table 1).

Table 1. Effect of oil palm's age on microclimate stands

\begin{tabular}{cccc}
\hline \multirow{2}{*}{ Microclimate parameters } & \multicolumn{3}{c}{ Oil palm's age (year after planting) } \\
\cline { 2 - 4 } & 5 & 8 & 12 \\
\hline Air temperature $\left({ }^{\circ} \mathrm{C}\right)$ & $28.24 \mathrm{~b}$ & $30.01 \mathrm{a}$ & $30.96 \mathrm{a}$ \\
Soil temperature $\left({ }^{\circ} \mathrm{C}\right)$ & $23.73 \mathrm{a}$ & $22.62 \mathrm{~b}$ & $22.54 \mathrm{~b}$ \\
Radiation energy $\left(\right.$ watt $\left.\mathrm{m}^{-2}\right)$ & $198.33 \mathrm{~b}$ & $247.21 \mathrm{a}$ & $256.84 \mathrm{a}$ \\
Relative Air Humidity $(\%)$ & $74.98 \mathrm{a}$ & $69.15 \mathrm{~b}$ & $68.66 \mathrm{~b}$ \\
\hline
\end{tabular}

This finding was slightly different from the Wasito et al. (2014) which stated that solar radiation energy decreases with increasing age of oil palm, but in accordance with the opinion of Ismail et al. (2009) which stated that photosynthetically active radiation (PAR) passing through the leaf canopy increased with distance from the palms. PAR reaching the soil surface was higher at the center of the area between the palm rows or between two avenues (Haniff et al., 2003). According to Mahmud (2017) radiation decreased by 198.62 watt. $\mathrm{m}^{-2}$ between oil palm aged 10 years compared to 4 years. The observation on temperature and air relative humidity was accordance with Wasito (2014) that there was an increase in temperature of $0.59{ }^{\circ} \mathrm{C}$ and a decrease in air relative humidity of $13 \%$ between oil palm aged 10 YAP compared to age 4 YAP. 
The age of oil palm is directly proportional to the difference between air and soil temperature under oil palm stands. An increase in air temperature from 0.95 to $2.72{ }^{\circ} \mathrm{C}$ was happened in plants aged 5-15 years. Soil temperature fluctuations in different oil palm age were relatively low, but the difference between air and soil temperature in plants aged 5-15 years increased between 1.03 to $3.91{ }^{\circ} \mathrm{C}$.

These findings indicate that the relative humidity under palm oil in all observed ages is still appropriate for the growth of liberica coffee since it has similar requirements for growing with robusta coffee. According to DaMatta (2004) robusta is successfully grows under high air humidity approaching saturation, or in less humid sites, provided that the dry season is short.

\subsection{Distribution of Oil Palm and Coffee Roots}

When two or more crops are subjects to intercropping, the interaction between each component crop will be sharing, competition, or both. Interactions are based on above- and below-ground. It accounts for light, water, and nutrient as growth resources, subject to competition and sharing (Khasanah et al., 2016). The aim of implementing an intercropping system is to optimalize sharing and minimize competition among the constituent crops. If crop not choose correctly, the crops can compete with each other for resources such as water, nutrient, light, and growing area which cause negative yield results (Nchanji et al., 2015).

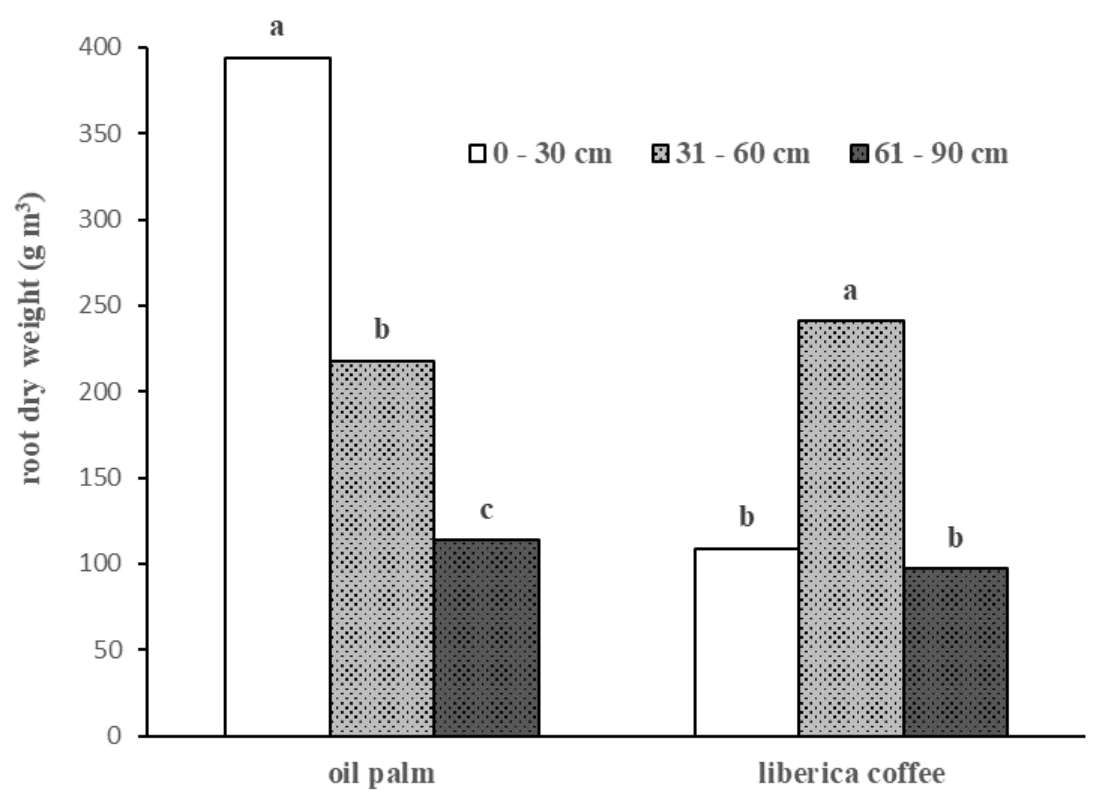

Figure 1. Vertical distribution of oil palm and coffee root in the intercropping system $\left(\mathrm{g} \mathrm{DWm}^{-3}\right)$

One of the basic considerations for implementing an intercropping cultivation system is the vertical and horizontal distribution of roots from each crop as a part of intercropping. Root system distribution is directly linked to the various functions ensured by the roots such as water and nutrition absorption. The characteristics of growth and distribution of roots will affect the distance and cropping pattern of intercropping system. 
Oil palm roots were dominantly distributed vertically in solum $0-30 \mathrm{~cm}(54.3 \%)$, and decreased to $30.1 \%$ and $15.7 \%$ in solum $31-60 \mathrm{~cm}$ and $61-90 \mathrm{~cm}$, respectively. Solum $0-30 \mathrm{~cm}$ was dominated by tertiary roots and a few secondary roots. Secondary roots dominated in $31-60$ $\mathrm{cm}$, and $>60 \mathrm{~cm}$ solum. This finding is in accordance with Safitri et al. (2018) which states that the roots of oil palm in favorable condition when all growing factor are available grow only to a depth of $1 \mathrm{~m}$. However, according to Corley and Tinker (2003) it can reach more than $5 \mathrm{~m}$ if the soil as growing medium cannot provide sufficient growth factors, especially water.

The results showed that coffee roots had different distribution characteristics. Its dominant distribution was in solum $31-60 \mathrm{~cm}(53.9 \%)$, while the distribution in solum $0-30 \mathrm{~cm}$ and $61-$ $90 \mathrm{~cm}$ was relatively same, 24.4 and $21.7 \%$ respectively. According to da Silva et al. (2016) mature coffee roots concentrated in the upper soil layer, while the presence of roots detectable until 1.45 $\mathrm{m}$ depth. In areas close to the periphery of the liberica coffee canopy projection, the number and the depth of roots gradually decreasing (Rena \& Guimarães, 2000).

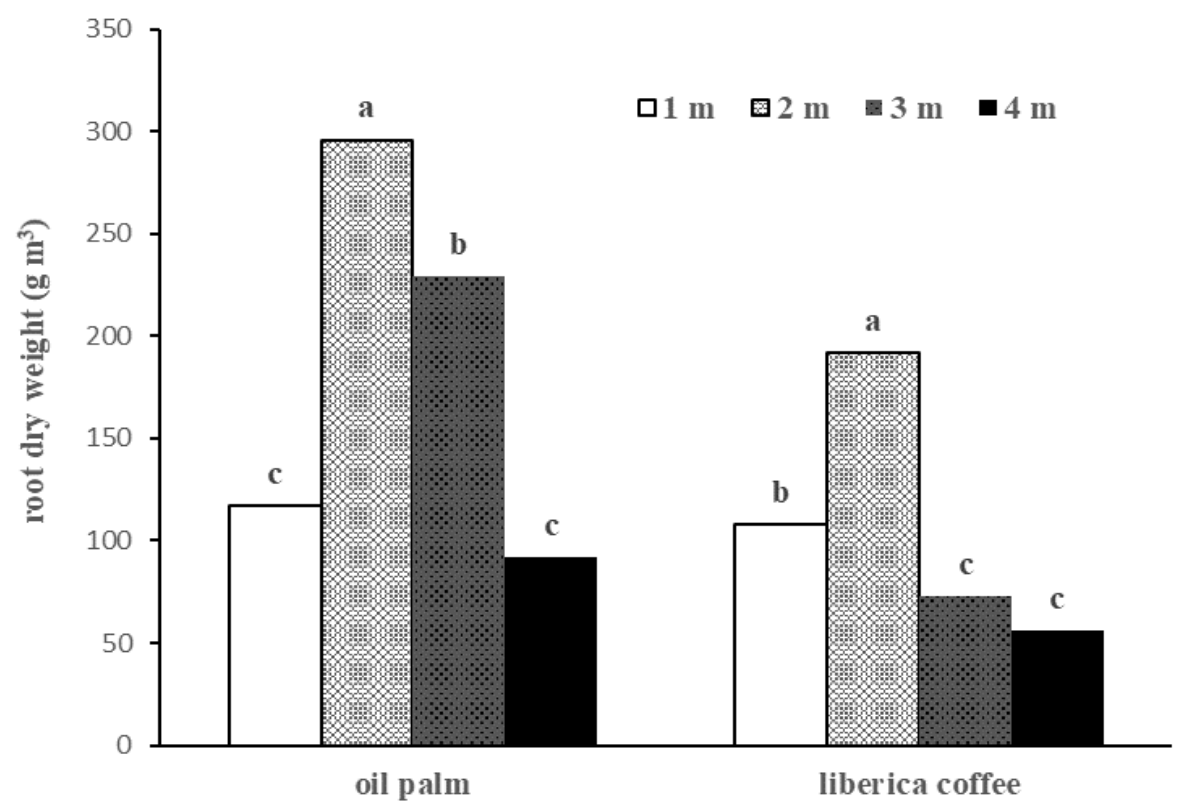

Figure 2. Horizontal distribution of oil palm and coffee roots in the intercropping system ( $\left.\mathrm{g} \mathrm{DW} \mathrm{m}^{-3}\right)$

There are main roots, tap roots, and lateral roots which grow parallel to the ground. Analysis results show the tap roots extend no further than $30-45 \mathrm{~cm}$ below the soil surface. These observations are in accordance with the da Silva et al. (2016) which states that about $80-90 \%$ of the feeder root is in the first $20 \mathrm{~cm}$ of soil and is $60-90 \mathrm{~cm}$ away from the trunk of the coffee tree. Damatta and Ramalho (2006) states that the biggest root concentration is in the 30 to $60 \mathrm{~cm}$ depth.

Liberica coffee trees have a deeper root system, which means they're more robust and able to access water deeper than other varietals. They can therefore be grown in harsher climates, and even in soils that might not be viable for other trees such as heavy clay and peatland. Liberica, being bigger than both arabica and robusta, also has a much more extensive root system. The roots 
of liberica go much deeper than any other coffee tree (Anonim, 2019). Observations were also performed on the horizontal distribution of roots. The results were showed in Figure 2.

It was known that $71.5 \%$ of oil palm roots are distributed at a distance of $2-3 \mathrm{~m}$ from the trunk while the coffee roots are dominantly distributed at a distance of 1-2 $\mathrm{m}(69.9 \%)$. Competition for resources (water and nutrients) in the intercropping system mainly occurs only if the roots of both crops are in the same field. In this case, the largest overlap of roots occurs at a distance of $3 \mathrm{~m}$ from oil palm's trunk, where there were $17 \%$ of oil palm roots and $11 \%$ of coffee roots at the same distance and solum. Oil palm and liberica roots distribution showed a different pattern (Figure 3).

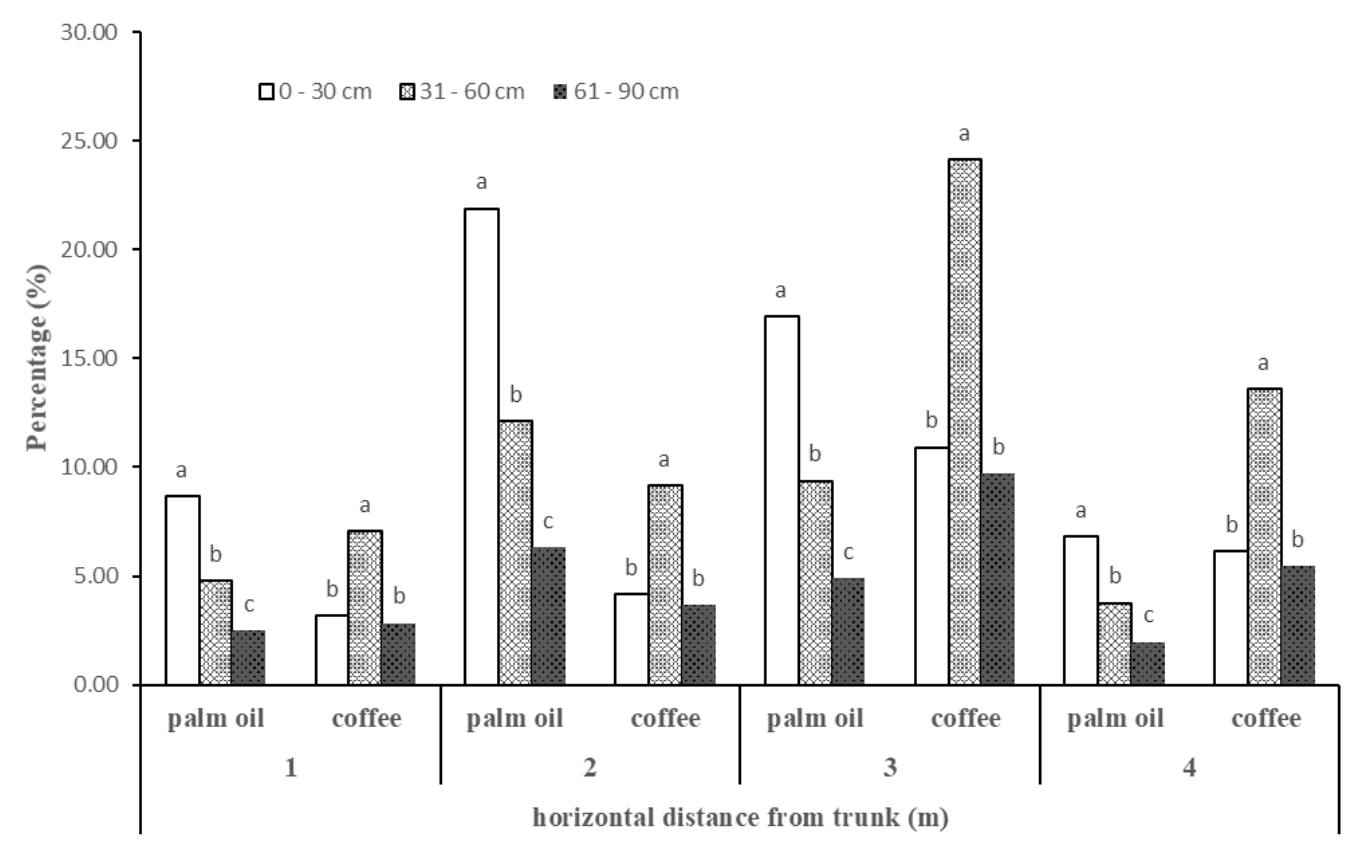

Figure 3. Horizontal distribution of oil palm and coffee roots in different solum (\%)

Oil palm had a consistent distribution of roots in the shallow solum $(0-30 \mathrm{~cm})$, and always dominant compared to coffee at all horizontal distances observed. The largest roots distribution was at a distance of $2 \mathrm{~m}$, followed by a distance of $3 \mathrm{~m}, 1 \mathrm{~m}$, and the lowest at a distance of $4 \mathrm{~m}$ from stem. On the other hand, the distribution of coffee roots mostly dominates the medium solum (30-60 cm), except at a distance of $2 \mathrm{~m}$ from the trunk.

The largest coffee roots distribution is at a distance of $3 \mathrm{~m}$, followed by a distance of $4 \mathrm{~m}$, $2 \mathrm{~m}$, and the lowest at a distance of $1 \mathrm{~m}$. Oil palm roots dominated more than coffee except at a distance of $3 \mathrm{~m}$ from the trunk in solum $30-90 \mathrm{~cm}$ and 4 meters from the trunk at all solum. These results indicated that the potential for competition between oil palm and liberica coffee was relatively small, given the canopy architecture and rooting distribution of each crop.

The adequacy of growth factors was indicated by the productivity of a crop. Analysis of oil palm yields in the intercropping system showed no significant decrease compared to monocropping systems in the location with relatively the same age and production input. The decline only occurred in oil palm aged 12 years, but it is not certain that the cause of the $4.7 \%$ 
decline in production was due to intercropping practices alone. According to Corley and Tinker (2003) the reproductive development of oil palm from the flowers initiation to the maturation of fresh fruit bunch (FFB) takes between 24-26 months, so it takes longer observation time in order to draw conclusions as to the cause of the decline in production.

Different findings are shown in coffee production. Observations in the first year of research showed productivity per tree in the intercropping system decreased between $25-30 \%$ compared to monocropping systems. The average production in Tanjung Jabung Barat regency which is the

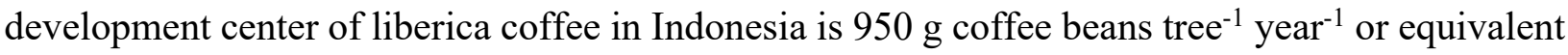
to $950 \mathrm{~kg}$ coffee beans tree ${ }^{-1}$ year $^{-1}$ with a population of 900-1000 trees hectare $^{-1}$ (Waluyo \& Nurlia, 2017). The average production at the study site with the monocropping system is $560-770 \mathrm{~g}$ coffee beans tree ${ }^{-1}$ year $^{-1}$.

\section{Conclusions}

The results of this study indicate that intercropping between oil palm and liberica coffee is possible because it does not cause a decrease in oil palm production as the main crop. Horizontally, oil palm roots are dominant at a distance of $2 \mathrm{~m}$ from the trunk, while coffee roots are dominant at a distance of $3 \mathrm{~m}$ from the trunk. Assuming the distance between oil palm and coffee is $4.5 \mathrm{~m}$, it is possible to overlap between the roots of the two plants, but because both plants have different vertical root dominance, where oil palm has a dominant root distribution at 0-30 cm solum, while coffee root is dominant at solum $30-60 \mathrm{~cm}$, the competition for factors of production and space is minimal. Nevertheless, it is necessary to analyze the feasibility of farming in a longer time period by considering economic factors.

\section{Acknowledgement}

I express my gratitude and appreciation to Mr. Sriyono for his outstanding technical assistance during the research and all farmers in in Kepenuhan Raya Village, for their willingness to participate in this research. I also thank to Mrs. Pauliz Budi Hastuti as a peer reviewer so that this article can be completed.

\section{References}

Anonim. (2019). Directory of Palm Oil Plantations Establishment 2018. Jakarta, Indonesia: Central Bureau of Statistics.

Ceulemans R. \& Saugier B. (1993). Photosynthesis. In: Raghavendra AS (ed), Physiology of Trees. New York, United States: John Wiley \& Sons.

DaMatta, F. M., Ronchi, C. P., Maestri, M., \& Barros, R. S. (2007). Ecophysiology of coffee growth and production. Brazilian Journal Plant Physiology. 19(4), 485-510. https://doi.org/10.1590/S1677-04202007000400014

DaMatta, F. M. (2004). Ecophysiological constraints on the production of shaded and unshaded coffee: a review. Field crops research, 86(2-3), 99-114. https://doi.org/10.1016/j.fcr.2003.09.001

DaMatta, F. M., \& Ramalho, J. C. (2006). Impact of drought and temperature stress on coffee physiology and production: A review. Brazilian Journal of Plant Physiology. 18(1), 55-81. 
Goh, K. J. (2000). Climatic requirements of oil palm for high yields. Proc. Seminar on Managing Oil Palm for High Yields: Agronomic Principles. Kuala Lumpur. Malaysia: Malaysian Society of Soil Science/Param Agric. Surveys

Harun, M. U., Lestari, I., Nusyirwan, N., Sodikin E., \& Irsan C. (2018). Polyculture of various varieties of upland rice with oil palm on dry land. 2018 Suboptimal Land National Proceedings Seminar, Palembang.

Ismail, S., Khasim, N., \& Omar, R. Z. R. (2009). Double-row Avenue system for crop integration with oil palm. MPOB Information Series, 465(424), 1-4. Retrived from http://palmoilis.mpob.gov.my/publications/TOT/TT-424.pdf

Khasanah, N., Van-Noordwijk, M. \& Hairiah, K. (2016). Intercropping Oil Palm: A Tree-soilcrop Interactions Model. Nairobi, Kenya: ICRAF World Agroforestry.

Kingra, P. K., \& Kaur, H. (2017). Microclimatic modifications to manage extreme weather vulnerability and climatic risks in crop production. Journal of Agricultural Physics, 17(1), 1-15. Retrived from https://www.researchgate.net/publication/331248969

Koh, L. P., \& Wilcove, D. S. (2008). Is oil palm agriculture really destroying tropical biodiversity? Conservation letters, 1(2), 60-64. https://doi.org/10.1111/j.1755-263X.2008.00011.x

Luskin, M. S. \& Potts, M. D. (2011). Microclimate and habitat heterogenity through the oil palm lifecycle. Basic and Applied Ecology. 12, 540-551. https://doi.org/10.1016/j.baae.2011.06.004

Mahmud, A. (2017). Kajian Budidaya Padi (Oryza sativa L.) Sebagai Tanaman Sela Pertanaman Kelapa Sawit (Elaeis guineensis Jacq.) (Thesis). Retrived from http://repository.umy.ac.id/handle/123456789/15358

Haniff, M., Suboh, H., Fildia, I. D., Shahabudin, A. M., \& Aminah, K. S. (2003). Light interception and leaf area index measurements from three different oil palm planting systems. $14^{\text {th }}$ Malaysian Society of Plant Physiology Conference. Genting Highlands.

Nchanji, Y. K., Nkongho R. N., Mala W. A. \& Levang P. (2015). Efficacy of oil palm intercropping by smallholders. Case study in South-West Cameroon. Agroforest System. 90: 509-519. https://doi.org/10.1007/s10457-015-9873-z

Perez, R. P.A., Dauzat J., Pallas B., Lamour J., Verley P., Caliman J. P., Costes E. \& Faivre R. (2017). Designing oil palm architectural ideotypes for optimal light interception and carbon assimilation through a sensitivity analysis of leaf traits. Annals of Botany. 121(5):1-18. https://doi.org/10.1093/aob/mcx161

Rena, A. B. \& Guimarães P. T. G. (2000). Sistema radicular do cafeeiro: estrutura, distribuição, atividade e fatores que o influenciam. EPAMIG. 80 p. Belo Horizonte

Safitri, L., Suryanti, S., Kautsar, V., Kurniawan, A., \& Santiabudi, F. (2018, March). Study of oil palm root architecture with variation of crop stage and soil type vulnerable to drought. In IOP Conference Series: Earth and Environmental Science (Vol. 141, No. 1, p. 012031). IOP Publishing. https://doi.org/10.1088/1755-1315/141/1/012031

Trisna, Wiryono, \& Apriyanto E. (2018). Analisis Tumbuhan Bawah pada Kelapa Sawit Umur 2 Tahun (TBM) dan 8 Bulan (TI) di PT. Bio Nusantara Teknologi, Bengkulu Tengah, Provinsi Bengkulu. Jurnal Agriculture, 12(1), 11-20.

Turner, P. D., \& Gillbanks, R. A. (1974). Oil palm cultivation and management. Kuala Lumpur, Malaysia: Incorporated Society of Planters.

Vaast, P., Bertrand, B., Perriot, J. J., Guyot, B., \& Génard, M. (2006) Fruit thinning and shade improve bean characteristics and beverage quality of coffee (Coffea arabica L.) under optimal conditions. Journal Scientific Food Agriculture. 86: 197-204. https://doi.org/10.1002/jsfa.2338

Vicente, M. R., Mantovani, E. C., Fernandes, A. L. T., Neves, J. C. L., Figueredo, E. M., \& Delazari, F. T. (2017). Spacial distribution of fertigated coffee root system. Ciência $e$ Agrotecnologia, 41(1), 72-80. https://doi.org/10.1590/1413-70542016411021316

Waluyo, E. A. \& Nurlia A. (2017). Potential Development of Liberika Coffee (Coffea liberica L.) 
Agroforestry Patterns and Its Marketing Prospects to Support Peatland Restoration in South Sumatra (Learning from the District of Tanjung Jabung Barat, Jambi Province). Proceedings of the 2017 National Suboptimal Land Seminar, Agricultural Science and Technology Development with Local Farmers for Optimizing Suboptimal Land. Palembang.

Wasito, K., Ramijah E. L., Khairiah, \& Hermanto, C. (2014). Optimization of Gogo-Based Palm Oil Plantation Land Supports Food Security in North Sumatra. Retrieved from http://www.litbang.pertanian.go.id/buku/swasembada/BAB-II-6.pdf. 